\title{
Flight Trajectories and Changing Camp Perceptions: Divergent Evidence from Zambia and Angola
}

\author{
Katharina Inhetveen
}

Life in Meheba is difficult, because for you to have something to eat, you have to struggle. Also for you to go to the clinic, to the hospital, you have to pay. ... And life as a whole is not very clear to us.

So for that reason, we better go back to our country.

(Camp refugee, Zambia 2003)

There where we were, in our friends' country, we were kept well.

We ate and drank I don't know how much. (Returnee, Angola 2011)

\section{Introduction}

How do people experience life in refugee camps? When I talked to refugees from Angola in Zambian camps, even though they were thankful for being safe from the Angolan war, their dominant assessment of camp life was that it meant suffering, deprivation and disregard. Several years later and after returning to Angola, however, 
former refugees remembered being well cared for in Zambian camps, while the notion of suffering was more closely associated with life as a returnee in Angola. How could I account for these discrepancies? Did people, after their return, misremember the living conditions in the camps? Are we dealing with a case of nostalgia for a bygone life-world or social order that was experienced as adverse at the time, maybe even cruel, but appears relatively desirable in a difficult present? ${ }^{1}$ Or did the refugees only complain during their stay in the camps because they didn't anticipate how bad it would be in post-war Angola, or because they saw the past in Angola through rose-colored glasses? Maybe they complained during my camp research mainly to try and get support from an unknown, but potentially resourceful European researcher? I traced the different assessments of life in refugee camps more systematically in the empirical material from both the research on camps and the project on refugee return, and I do not think that any of these possible explanations suffices to make sense of the diverging representations of camp experiences. Moreover, I don't believe that we need to decide - as these explanations would suggest - which of the different evaluations or experiences is to be seen as "correct" or "authentic".

Below, I will depict the tendencies of divergence between in-camp and postreturn assessments of life in refugee camps along three dimensions, corresponding to three recurring evaluation criteria: food and health, mobility, and dignity and respect. I will then share my thoughts on the methodological consequences of these discrepancies, and on the implications for our understanding of refugee camps as stations in more encompassing flight trajectories, experienced in the context of mobility biographies. First of all, though, I will briefly introduce the two research projects I draw on.

Both projects were set in the context of the Angolan wars and flight movements that took place from the 1960s onwards. The first organized violent attacks against the Portuguese colonial rulers, which coalesced into an anticolonial war, date back to 1961. ${ }^{2}$ The armed conflict between Portuguese troops and different Angolan liberation movements lasted until 1974, when the Portuguese regime was toppled by the Carnation Revolution. Two of the resistance groups in this anti-colonial war became the main opponents in the decades-long civil war that started shortly after official independence in 1975; these were the MPLA (the "People's Movement for the Liberation of Angola"), which assumed power after independence and has been Angola's governing party ever since, and the UNITA (the "National Union for the Total Independence of Angola"), which went to the bush to fight the government militarily (and also, as the slogan went, with hoe and pencil). Even though this civil

1 This phenomenon is the subject of current debates on "black Apartheid nostalgia" (Paret 2018: 678) in South Africa. While the Apartheid regime is clearly a more dire case than the Zambian refugee camps, it also applies here that "Nostalgia for then does not and cannot exist unless in dialogue with an unsatisfactory now", as Reed (2016: 99) notes with regard to South Africa. I would like to thank Mario Krämer for bringing the discussion on the South African case to my attention.

${ }^{2}$ On the memory politics of (re-)defining Angolan war history, including the 1961 events, see Schubert 2015 . 
war featured characteristics of what is known as a proxy war (with the West supporting UNITA and the East supporting MPLA), it continued after the end of the Cold War with only brief phases of relative calm (see for example Brinkman 2007; Weigert 2011). The fighting lasted until UNITA leader Jonas Savimbi was killed by government troops in February 2002. The MPLA rule solidified, and post-war Angola became shaped by a regime in which the governing elite tightly controlled political and economic life (see Soares de Oliveira 2015).

In 2003, I spent six months doing field research in two Zambian refugee camps, as part of a research project which focused on the political order of refugee camps (Inhetveen 2010). The first camp I visited was Meheba Refugee Settlement in Zambia's North-Western Province, a large camp founded in 1971, in which all refugee families received housing and farming plots, and the refugee population of up to 50,000 residents came from different regional, economic, and political backgrounds. At the time of my field research, most of them came from Angola, though the population was multi-national, including refugees from Congo (DRC), Rwanda, Burundi, Somalia, Uganda, and Sudan. Nangweshi Refugee Camp in Zambia's Western Province, the second research site, had existed for only three years at the time of my fieldwork. It was founded specifically for a large group of UNITA affiliates who had fled from Jamba, the party's former stronghold in Angola's Cuando Cubango province, when government troops attacked it around Christmas 1999. In Nangweshi, all families depended on WFP food rations and lived on small, densely-set housing plots. In both camps, I spoke with and observed the different organizational actors involved in camp management and camp life, but of course I also interviewed refugees, mostly with the support of my local research assistants, André Melo (Meheba) and Hildah Njamba (Nangweshi). I learned from these interviews that many refugees experienced camp life as suffering. Their descriptions of the difficulties they faced living in refugee camps made up a considerable part of our conversations, and covered many aspects of daily life and future planning.

During my field research in Meheba, UNHCR started organized "voluntary repatriation"3 from Zambia to Angola. Many refugees went back to Angola in the years that followed, also from the Zambian camps, including Meheba and Nangweshi. I thus initiated a follow-up project to investigate how returning refugees, and especially local leadership figures, (re-)integrated into local political orders, and if and how cultural elements that the agencies in the camps had set out to teach the refugees were transferred to the country of return (for a recapitulation of the project, see Inglês et al. 2017). Fieldwork in this project was conducted by Christoph Kohl, for the most part together with local research assistant André Melo, himself a returnee who had also been a camp inhabitant and my local research assistant in Meheba in 2003. The systematic data analysis of the collected material, based on Grounded Theory strategies (Strauss 1987), was conducted by Paulo Inglês, Sandra Schmid (née

\footnotetext{
3 On the difficult question of voluntariness in organized "voluntary repatriation" (or "VolRep" in humanitarian speak), see Inhetveen 2010: 218 ff.; see also Amore 2003.
} 
Lehner), and myself. The interview material from this second project repeatedly contains references to the camp life the returnees experienced during their exile in Zambia - and at first, I was admittedly surprised by the divergence between these expost accounts of camp life and the assessments I had heard in Meheba and Nangweshi. In retrospect, those interviewees who mentioned their former camp life in Zambia mostly evaluated it in positive terms, especially compared to their current life in Angola, as their country of return (and, for those who had not been born in exile, their country of origin). However, the returnees' past experiences in refugee camps were not the focus of this research project, and they occur rather occasionally in the material. Thus, the comparison I attempt here, between evaluations of camp life made while living in a refugee camp versus those made after returning to Angola, is really a by-product of the two research projects. In addition, neither the people interviewed in the Zambian camps nor those interviewed in Angola were homogeneous populations: the material contains assessments of camp life in two different camps, from people with diverging backgrounds and flight trajectories, and from equally different people living in widely varying contexts in Angola. As the following thoughts are only a by-product of two differently focused studies, though, the data do not allow a systematic correlation between these different backgrounds and emic categorizations of people on the one hand and their (changing) evaluations of camp life on the other hand. Rather, when I now re-read the material which was collected with other questions in mind, my findings can only be preliminary indications - but hopefully the patterns observed in this comparison can serve as food for further thought.

\section{Evaluations from Zambian Camps and Angolan Hindsight}

Notwithstanding the complexity of evaluations and their contexts as they appear in the field material, there is an observable pattern of systematic discrepancy in the assessments of camp life made by camp inhabitants on the one hand and by returnees back in Angola on the other hand. To highlight this pattern, I will use unambiguous quotations, at the risk of overemphasizing the differences between assessments from camp versus return situations. This should be kept in mind, but the selection seems justifiable for the benefit of the argument, as my intention is to trace and discuss an observable divergence without expressing this pattern in exact figures. With this qualification in mind, let me summarize the diverging assessments made during camp life and after return: 
In interviews carried out in the camps, the refugees predominantly evaluate camp life as suffering, or even "grand suffering" (P91_Zam,4 translated from Luvale"). When I ask an older refugee how he will remember Nangweshi Camp after his return to Angola, he answers in his native language Umbundu and everybody present starts laughing, including myself, although I did not understand his words: His gesture made it very clear that he did not see any reason for remembering the camp - and my assistant confirmed this by translating: "There is nothing here!" (P148_Zam). As we learn from more detailed assessments in other interviews, suffering as a refugee is about poverty, about restriction of movement, and about a lack of dignity. Being a refugee is given as a reason for all kinds of deprivation. Correspondingly, another inhabitant of Nangweshi Camp emphasizes: "Como refugiado, nada é suficiente" (P168_Zam). ${ }^{6}$

This widespread assessment cannot be explained away completely by arguing that some of the respondents assumed I was a person with the power to improve their living conditions in the camp. The experience of suffering as a camp refugee is confirmed by people who came to know me better, and it is reported in literature based on field research in Meheba and other refugee camps (Barrett 1998: 27 ff.; Hoeing 2004; McConnachie 2014: 41f.; Powles/Clark 1996: 9, 11). Even though our interviewees in the camps frequently express their gratitude to Zambia or UNHCR to have safeguarded their lives in the refugee camps, and a few also laud the infrastructure and services, the most prominent experience of camp life that inhabitants of Meheba and Nangweshi express is shaped by suffering.

After having spent much time examining the material from the refugee camps and with the assumption that I therefore knew something about how refugees saw life in camps - I was surprised at first that the interviews with returnees in Angola contain quite different depictions of camp life, even though I had heard that some returnees went back to Zambia after only a couple of months in Angola. Having in mind the many negative assessments of camp life I had heard in Meheba and Nangweshi, I was baffled as to why conditions in the Zambian camps are praised in the Angolan material. The basic tendency in the post-return material is summed up in the following statement made by a Chief:

When people were getting aid from UN Refugee Agency was better than the government organ of MINARS [Ministério da Assistência e Reinserção Social; KI]. ... In Meheba, though we were refugees, we were well-off. The paradox is that a person has a better life in foreign land than in one's own home: This is hard to grasp. (P17_Ang, translated from Lunda)

4 The suffix "ZZam" in an interview identifier denotes material from the Zambian camps, the suffix "_Ang" material from returnees in Angola. As the material from each project was analyzed in a separate Hermeneutic Unit (using the QDA software ATLAS.ti), documents (in this case interview transcripts) from the two projects may have the same document number and are thus differentiated by the suffix.

${ }^{5}$ On the use of oral and written translations in multi-language research sites such as refugee camps, with further information about the camp research project in Zambia, see Inhetveen 2012.

6 "As a refugee, nothing is sufficient." 
Another Chief, when interviewed in Meheba, talked about the "refugee problems", the difficulties of camp life, and the wish of people to go back to Angola, because, as he put it: "In running away, there is suffering, not life" (P80_Zam, translated from Luvale). In a conversation with him and his assistants in Angola, eight years later, his assistant compares camp life with existence as a returnee in Angola:

... talking about the people of this chiefdom Likonge they are suffering. The government is not paying any attention to us. It is not like the time we stayed in Meheba. Medicines were free from government. And that saved many lives of people. But coming here, if you try to go around the village, you will find almost everyone in their house down with illnesses. They have no medicine. ... We are not living well at this village. Government is supposed to pay more attention. "Kwalisa koma kuli yove ivene" [a congregation/event can only be make live by the owners/participants/people involved; $\left.\mathrm{AM}^{7}\right]$. If you the government forget about your people, they will suffer. (P19_Ang, translated from Luvale)

To detail the discrepancies between camp evaluations made in Zambia and in Angola, I will compare statements from the camps with post-return statements along three dimensions of "suffering". These correspond to three criteria of evaluation that are frequent in both camp and returnee interviews, namely (1) food and health, (2) mobility, and (3) dignity and respect.

\subsection{Livelihood in Camps: The Dimension of Food and Health in Camp Evaluations}

\section{Livelihood in Camps: Zambian Camp Perspectives}

In Zambia, all camp refugees get food rations from WFP upon arrival. In camps without farmland, like Nangweshi, the inhabitants receive rations as long as they stay in the camp. In refugee settlements like Meheba, where each household is assigned a farming plot, food rations are only distributed to "new arrivals", that is, during the first two years a person lives in the camp. Either way, in explanations of "suffering", food is a central topic (see Pottier 1996 on Goma, a different case with some similar features). In my conversations with refugees both in Meheba and Nangweshi, many of them consider the food there as being barely sufficient, both in quantity and quality, and also in comparison with the food available in Angola. The camp refugees' discontent is formulated both in general terms, and with regard to specific problems, such as always being given peas in the WFP food rations. A refugee woman in Meheba explains:

\footnotetext{
${ }^{7}$ By adding several translations separated by a slash, translator André Melo indicates several possible associations with the original word or formulation.
} 
Eating peas, (for?) children it's diarrhea. We ourselves also, just like this. For me I cook them but when I try to eat them, in the stomach it's work. (P73_Zam, translated from Umbundu)

In Nangweshi, where people talked to me mostly in Portuguese, even the way interviewees pronounce the word ervilha (pea) makes clear how averse they are to this component of the rations, which is provided to supply the camp residents with proteins (Sphere Project 2000):

Ninguém consegue comer ervilha de manhã ao, as doze, a noite, durante uma semana ervilha, ervilha, ervilha, todo dia, não, então não é possível, não é possível, nunca. ${ }^{8}$ (P182_Zam)

Refugees like the man quoted here can become almost agitated about the topic of peas, even though they have talked quite matter-of-factly during most of the conversation. Especially in Nangweshi, complaints about the unbearableness of the food rations repeatedly culminated in remarks about the peas. The refugees try to supplement their food rations by trading parts of them for other edibles, a practice that is problematized by some of the aid agencies as illegitimate use of the rations (see also Turner 2010).

In addition to complaints about the food situation, camp refugees often criticize health services as being inaccessible or expensive - sometimes generally, sometimes concretely, for example with regard to a child's deformed leg that remains untreated. As one example out of many, a refugee in Meheba renamed José Musole, whom we have asked what he will tell people in Angola about life in the refugee camp, answers:

We shall tell them (clearing his throat), we shall tell them about, life in Meheba, about, suffering, about ... lack of clothings, about hunger, about lack of enough, ... food, enough proteins, yeah, just proteins. Then we shall also explain to them how difficult it is to go to the, to the clinics because you need to pay for everything and with people who are already old, how difficult it is to have them made attended to. (P70_Zam, translated from Luvale)

His explication of the components of "suffering" continues after the quoted segment, but the central role of food and medical services becomes clear. In this case, the speaker is not among those camp inhabitants who receive a monthly ration, but one of those who, after having lived in Meheba for more than two years, are expected to be self-sufficient on the basis of cultivating their assigned farming plots. In his assessment, the difficulties in accessing medical services are related to financial rather than logistical problems.

8 "Nobody can eat peas in the morning at, at noon, in the evening, during one week peas, peas, peas every day, no, so this is not possible, it is not possible, never." 


\section{Livelihood in Camps: Angolan Hindsight}

Eight years later in Angola, very different accounts were given by returnees regarding food, water and health services in the Zambian refugee camps.

Chief Manuel Chiyaze, whom we had also spoken with in Meheba - and who had been one of the relatively few interviewees who saw conditions in the camp as quite positive - compares his life after return with that in the refugee camp:

In Meheba we had many water pumps, but here we have nothing. Look at the water we are drinking. We are asking from government, "where is the medicine to treat our water?" If you've followed me recalling our discussion in Meheba, yes, I discussed with her/him, we blessed each other, embraced/hugged for having kept us well, with facilities like schools, medicines/health, water and sanitation. ${ }^{9}$ This is why we blessed them. Even now some are still there [in Zambia]. When they come here and find that we don't have medicines, they decide to go back. I am grateful for having to come to look for me in this country. ... We reached well, but we have problems with medicines. (P14_Ang, translated from Lunda)

The water infrastructure in Meheba, mainly based on India Mark II handpumps installed throughout the camp area, indeed seemed to meet people's needs. Interestingly enough, though, when we look back at the material from the camps, these wells are rarely mentioned in the Meheba interviews. In Nangweshi, though, the difficulties connected with the water system are mentioned more often, for instance by a refugee representative who said: "Water is not sufficient. Our women are fighting too much for the water. You find that in a short time water has finished in the tank" (P113_Zam, translated from Umbundu). There, treated Zambezi water from big tanks was accessible only at certain hours. In the resulting situations of queuing at crowded taps, problems and at times open conflicts occurred over water distribution. In Meheba, however, the water infrastructure lends itself to be contrasted with the difficulties that returnees experience in Angola.

The positive assessment of life in the camps, especially in Meheba, also pertains to food, and farming land. A 60-year-old returnee, Lurdes, explains:

In Meheba we [were] welcomed well and given plots to build our houses, land to cultivate and food. For instance, a kid was entitled to at least three liters of oil. So if one has five kids then would receive about 10 liters of oil. We also received a kind of fish called "lapa jimbo" [literally translated as "hit with the axe" alluding to the fact that it was big and hard thus required one to use an axe instead of a mere kitchen knife to cut it; AM]. This helped us a lot as we were cultivating our own food as well. We enjoyed this status for more-less three years and thereafter the authorities started reducing these hand-outs

${ }^{9}$ In the context of this enumeration of "facilities", the mentioning of "medicine/health" refers to medical care in general and not, as above, to a "medicine to treat our water". In UNHCR-led refugee camps, health constitutes an institutionalized project sector that is differentiated from Water and Sanitation (abbreviated as "WatSan" in humanitarian speak at the time of the research, now called "Water, Sanitation and Hygiene" or "WASH"); see Inhetveen 2010: 123. Thus, Chief Manuel Chiyaze is complimenting the camp in both respects and also with regard to the education sector. 
and in other cases completely cut. However, we still had food. We began to cultivate our own food .... (P11_Ang, translated from Umbundu)

Here, memory seems to multiply the food rations refugees received in the camp they consisted normally of 450 grams of maize (or 400 grams of maize meal), 120 grams of peas, 20 grams of cooking oil and 10 grams of salt per person per day. While many interviewees in the camps complain about the rations, some express gratitude for the food they receive, but people rarely praise the rations as adequate in quality and quantity, let alone generous. From a post-return perspective, however, the food available in the Zambian camps appears in a different light and can be remembered in a decidedly positive way.

\section{2 (Im-)Mobility in Camps: The Dimension of Freedom of Movement in Camp Evaluations}

\section{Mobility in Camps: Zambian Camp Perspectives}

A second crucial point in the experience of suffering is the limitation of movement for refugees. Officially, they are only allowed to leave the camp with a so-called gatepass, issued by the Zambian government representative in the camp, the Refugee Officer, and lasting up to one month. A group of refugees in Meheba declares accordingly: "Our movement has to do with gate passes, and it's like we are in prison" (P70_Zam, translated from Luvale). The camp refugees know very well how to leave the camp territory, which is enclosed by a "green" rather than a physical border. Even though, the regulations make them feel like being confined by a "wire", as people in Meheba also call the camp. While movement is physically possible, they risk going to jail if the Zambian authorities find them outside the camp without permission in the form of a gate pass. More concretely, refugees explain that their immobilization constrains their opportunities to earn money or organize food outside the settlement, and to visit relatives in other parts of Zambia. In Meheba, refugee farmers also complain that due to their immobilization, they have no fair access to the markets for their agricultural products. During my fieldwork, I observed how camp residents sold their maize harvest at a camp market to Zambian traders, who then took the maize to Zambian markets, for example in the Copperbelt, where they could sell it at a higher price. For the transportation of the maize, they hired the very same big trucks that had brought the WFP maize to the camp to be distributed as food rations for "new arrivals", while the refugee farmers found it hard to understand why WFP refused to buy their Meheba-grown maize for the rations. A refugee woman refers to these Zambian maize traders:

... those fellows who came to buy now, they are cheating us. You're getting/finding things, but the price is not there. They are just cheating you, you are just suffering. When farming, it is hard work, it is hard work. (P68_Zam, translated from Luvale) 
This refugee farmer feels betrayed by the Zambian traders who buy her maize harvest at beat-down prices, exploiting the fact that the refugees cannot easily go to the markets in larger Zambian towns themselves, given their restricted mobility. The "cheating" the refugees experience here is stated as part of their suffering as camp refugees.

\section{Mobility in Camps: Angolan Hindsight}

Back in Angola, the experiences of camp economics, including the connections between regulated mobility and trading, are remembered differently. A Chief already quoted describes:

In Meheba regardless of the refugee status, we were free to go and do business in other towns and with their own vehicles. Now we are suffering because Meheba was better. (P17_Ang, translated from Lunda)

His formulation "free to go" may refer to the green borders of the camp, which the refugees knew how to cross even without a gate pass. While refugees are not allowed to register motor vehicles of their own in Zambia, in this quote the chief possibly refers to an NGO project that financed a lorry to transport commodities between Meheba and the nearest town and provincial capital Solwezi. Indeed, in Meheba the fact that refugees were not allowed to register cars was not an issue interviewees talked about - while in Nangweshi it was well-known among refugees and staff that a certain car remained decommissioned in a yard for the years its displeased owner spent in the camp.

From an Angolan post-return perspective, the quoted chief looks favorably at the limited mobility that was possible in the camp. In this context, he explicitly compares Meheba with the post-return situation; thus, the positive evaluation of the camp experience is probably connected with this comparison. By contrast, the complaints uttered by many refugees living in camps must be understood against another argumentative back-drop and horizon of orientation.

\subsection{Dignity in Camps: The Dimension of Respect in Camp Evaluations}

\section{Dignity in Camps: Zambian Camp Perspectives}

The third dimension of camp evaluations already resonates in some of the complaints regarding to the first two dimensions: the question of dignity, of being treated with respect. Throughout the interviews with camp refugees, we frequently find feelings of being disrespected in comparison to nationals, mostly by Zambians, sometimes also by other agency staff. Repeatedly, interviewees connect the problems they face in camp life with their inferior status as foreign refugees. Edward Chinyemba in Meheba reasons: 
Some of these things are just being done to make us suffer, because we are refugees. Being in a foreign country we don't have power to argue and talk so much, even when things don't seem to be so good for us. (P62_Zam, translated from Luvale)

José Musole, who has already been quoted, summarizes his experiences by saying that "in this country where we ran to, we are people without dignity. ( $t)^{10}$ We don't have our ... dignity, our value" (P70_Zam, translated from Luvale).

In these accounts, the speakers depict experiences of lacking "power", "dignity", or "value" on grounds of being refugees and foreigners. This means, firstly, not having the power to pursue their interests and especially react to mistreatment, and, secondly, being identified as belonging to a category of inferior status and thus being denied the respect that citizens could expect. Even though camp refugees know how to utilize their refugee status as a resource for demanding certain rights under international law (Inhetveen 2006), the interviewees in the camps predominantly experience their refugee status as implying disadvantages with regard to both material rights and social esteem in the host country.

\section{Dignity in Camps: Angolan Hindsight}

Also in retrospect, after returning to Angola, some returnees associate the camp with a lack of rights. It is in this dimension that we find the most similarities between the assessments made in the camps and those made after return. Obviously, people remember refugeeness as an inferior status compared to Zambian citizenship, while acknowledging the protection and material support they received during their time in Zambia. An example is a woman who returned from Meheba and explains: "As escolas é que foram gratuitas e os hospitais também, mas outras coisas o angolano não tinha direito, não tinha direito o angolano"11 (P70_Ang).

Especially people who have come back from Nangweshi - that is, mostly refugees with UNITA affiliation - evaluate their treatment as refugees by the Zambians as clearly better than their treatment by the Angolan government led by the MPLA, which was the "inimigo", their "enemy", during the long war. One female returnee draws this comparison by saying that as refugees they were treated well by the Zambians, while it was the Angolan government who arranged for the camp inhabitants to be intimidated even in their country of asylum, Zambia:

... [O]s zambianos sabiam que os que estavam naquele campo de refugiados eram angolanos que estavam com a vida dedicada á UNITA, mas eles não intimidavam ninguém, até pelo contrário o consulado do MPLA que estava no Mungo (...) aqueles poquinhos que já eram do MPLA era quem eles ensinavam para já ir intimidar (...) $\mathrm{O}$ consulado pagava dinheiro para dizer: o Savimbi já morreu, a UNITA não existe, o MPLA vem aí e vão matar todos, então as pessoas ficavam assim com medo, esses eram

\footnotetext{
${ }^{10}$ In transcripts, a " $(\mathrm{t})$ " signifies a pause within a longer statement due to an oral in situ translation (see Inhetveen 2012).

11 "It was the schools that were free [of fees] and the hospitals also, but other things the Angolan had no right, he had no right the Angolan."
} 
(que?) intimidavam, não eram os próprios zambianos não, porque os zambianos sabiam que na Zambia a escolha também era livre, porque a Zambia já era um país democrático, ... os próprios zambianos tratavam-nos com muito carinho ${ }^{12}$ (P29_Ang).

This account refers to the persistent rumors in Nangweshi that the Angolan consulate in Mungo, capital of Zambia's Western Province, was secretly involved in trying to weaken enduring UNITA structures in Nangweshi Refugee Camp. One of the consulate's supposed tactics, as described here, was to pay some individuals among the refugees (the "very few who were with MPLA") to spread lies about the current state of UNITA and the power of MPLA. The speaker contrasts this with the way "the Zambians" treated the refugees: even though they knew that the refugees in Nangweshi had their "life dedicated to UNITA", they did not intimidate them. Quite the contrary, the Zambians are described as democrats, which serves as the explanation for their treating the Angolan refugees in Nangweshi "com muito carinho". The "free choice" characterizing a democracy is here extended to the refugees, who are not disadvantaged by the Zambians because of their UNITA affiliation.

Apart from the field observation that Zambia's and UNHCR's reactions to the persisting UNITA structures in Nangweshi were more ambivalent than described here (Inhetveen 2009), it is noteworthy that such accounts of political acceptance as "o povo da UNITA" ("the people of UNITA"; P168_Zam) by Zambians is less explicit in the material collected in Nangweshi. This retrospective appreciation may partly stem from the experiences of returnees, and especially of UNITA affiliates, back in Angola, where they experience discrimination, distrust and exclusion, not only by neighbors, but especially by the MPLA-controlled administration (Inglês et al. 2017).

With regard to the less politicized camp of Meheba, having been well-treated is also the overall assessment of Lurdes, whom I already quoted, when she talks about her time in Zambia. She came from Angola via Lusaka to Meheba in 1976 and says about the thirty years she spent in Zambia: "We were not ridiculed. Even the (successors?) of President Kaunda also maintained our status fairly well”' (P11_Ang, translated from Umbundu). Lurdes describes material and other difficulties she experiences in Angola after her return in 2006, like lack of food, of space, of building materials, of water, of jobs, and she concludes:

It is like we are in a foreign country and not our own. We are even regretting because one is not as free as it ought to be. Time and again, we are "pricked" in one way or the other.

12 "[T] he Zambians knew that those who stayed in this refugee camp were Angolans who were with the life dedicated to UNITA, but they intimidated nobody, even on the contrary, the consulate of the MPLA, which was in Mungo ... the few who were already of the MPLA were those whom they instructed to go and intimidate ... The consulate paid money for saying: Savimbi died already, the UNITA does not exist, the MPLA is coming here and will kill everybody, so like this the people became afraid, it was those who intimidated, it wasn't the Zambians themselves, no, because the Zambians knew that in Zambia also the choice was free, because Zambia was already a democratic country, ... the Zambians themselves treated us with a lot of solicitousness." 
Again, we find an outspoken contrast of acceptance (not being "ridiculed") in the refugee camp versus disrespect and disadvantages as returnees (being "pricked") in Angola, which thus does not feel like their "own country". This experience after return also contrasts with expectations and possibly memories of Angola while in the camp; Lurdes describes a kind of melancholic longing as a reason for deciding to return: 'Still one would be melancholic about one's home country, why shouldn't (we) go back home" (P11_Ang, translated from Umbundu). Not only does she express her disappointment regarding the Angolan government's material care for the returnees as Angolan citizens, but moreover, this disappointment is connected to a perceived lack of respect and freedom, and all these deprivations appear as different ways of being "pricked". Like many other former war refugees, she also describes "finger-pointing" by remainees ${ }^{13}$ targeted at returnees. ${ }^{14}$ Even though Lurdes does not broach the issue of party politics in the interview, she refers to a lack of freedom and connects it with the government. The freedom she misses also relates to her material living conditions, and she explains this by referring to an earlier historical horizon of comparison: the current Angolan government not only falls behind the Zambian refugee administration, but also disappoints the hopes of the anti-colonial struggle for freedom (in which the governing party MPLA played a major part):

Yet we fought against white colonialism so that we that we can be free and yet everything today is for the government only. This is where I will end, my son. We don't even know what to do. (P11_Ang, translated from Umbundu)

\section{Contemplating Divergent Evaluations of Camp Life}

\subsection{Reading and Conducting Camp Research}

When the discrepancies between these different assessments of camp life, stemming from refugees in Zambian camps on the one hand and from returnees in Angola on the other hand, caught my attention, my first reaction was astonishment. On second thought, I became aware of the degree to which I take accounts by interviewees as representing "their perspective" or "their interpretation" - that is, "their perspective" as such, without the qualification that this perspective, interpretation, or assessment is bound to a specific situation, which is likely to change, especially in flight or migration trajectories. This assumption also affects, for example, my reading of

\footnotetext{
13 The neologism "remainee" (Inglês et al. 2017: 108) denotes those people in post-war Angola who did not flee the country during the conflicts and return afterwards, but remained in Angola throughout the war. Creating a designation for this group corresponds to the view that remaining in a country in times of war should be no less an explanandum in (forced) migration and mobility studies than fleeing. Neither course of action constitutes a "normality" that does not require further consideration.

14 While many interviewees describe being discriminated against as returnees by both the administration and the general remainee population, this pertains particularly to UNITA affiliates. However, in postwar Angola both being a returnee and speaking Umbundu is frequently interpreted as an indicator that a person is close to UNITA (see also Inglês et al. 2017: 113).
} 
ethnographic material presented by colleagues, such as monographs on other refugee camps which are based on extensive fieldwork (e.g. Harrell-Bond 1986; Horst 2006; Turner 2010). I am not implying that these authors suggest a stability of people's assessments over time, but I realize that I (used to) read them with such an implicit presumption. While the renowned work of Malkki (1995) certainly points to the dependence of refugee perspectives on flight situations, her comparison is synchronic and thus does not rub our noses in the changes in refugees' assessments over the course of a flight trajectory (see also BenEzer/Zetter 2015: 313).

Moreover, interview situations seem to demand an assumption of stability regarding the evaluations that the interviewees present. In such conversations, it would be not only awkward, but also methodologically problematic to insinuate that whatever the interviewee says now in assessment of her experience will surely change in a different situation and is thus only a temporary assessment. It might well be that the situational assumption at the level of conversation often overshadows the analytic necessity to contextualize evaluations and accounts of experiences, and thus to be open for a dynamization of experiences and assessments in the course of flight trajectories.

When it comes to changes in assessments, and the imagined time-independent 'validity' of experiences, however, we do not have to refer to unusual situations (as flight and return might be for many readers), since many of us have most probably changed at least some of our own evaluations and interpretations of previous experiences. I think of myself as a school pupil - thoroughly enculturated and a daily participant in school life, which supposedly would have made me a good ethnographic informant about school (Spradley 1979: 47 ff.). Comparing what I thought and felt about school back then with my hindsight assessment today, I find anything but stability in my evaluations, and even what I feel as experiences. Is only valid and 'authentic', then, how I experienced and judged school during my school years, and my later assessments are biased and unusable, since I am not a properly enculturated field participant anymore? And again, as a pupil, I would possibly have answered yes, but today I have my doubts. To turn this question into a methodological one, under which conditions is it justified to treat ethnographic immersion as immanently superior to approaches that entail retrospect accounts? It rather seems to depend on the research problem whether the enculturated-participant perspective is the (only) one called for, or if it is more fruitful to include more, and also more distant, perspectives on the same experiences, instead of disregarding them as material of lesser value.

Even if we go exclusively for a reconstruction of enculturated-participant perspectives, we obviously cannot assume that interpretations of specific experiences will be stable in the course of an educational career, or a trajectory of flight and return, or more generally in the course of the perpetual dynamics of life. Sociologists will probably agree on this in principle, even without the usual inner-disciplinary controversies. I don't think, however, that we, as qualitative researchers in refugee studies, consider this observation sufficiently in our methodological and theoretical 
research practices. Especially in research on mobilities - among them flight, migration, return - it is methodologically crucial not to treat situations during specific phases along the way as quasi-static. We cannot expect evaluative accounts or experiences to be stable, and hence methodologically reproducible in studies conducted at different stages of a journey. Rather, we need to make explicit how perspectives are bound to a certain situation on a more encompassing trajectory of, for example, migration, flight, or return.

This would, in turn, have consequences for our strategies of comparison. Qualitative research should not only compare experiences and evaluations across different, synchronous contexts (even though more emphasis on such comparisons is desirable), but also diachronically between different phases of mobility trajectories. ${ }^{15}$ Follow-up studies would be useful, not as rushed as some multi-sited ethnographies, but rather in research intervals of several years, to allow perspectives, horizons of orientation, and even taken-for-grantedness to change. Admittedly, this is expensive, and often not compatible with academic career trajectories.

\subsection{Grasping Camp Experiences}

Apart from the methodological consequences we can derive from discrepancies in camp evaluations over time and mobilities, there is the question what we might learn from them about camp experiences. This line of thinking presupposes that we do not neutralize the contradictions by disregarding the changed post-return evaluations as pure hindsight bias, as general dismissals of retrospective interview research would suggest (see, for example, Silverman 2010: 192). Rather than insisting that we need to decide which one of contradictory assessments is 'true' and 'authentic', ${ }^{16} \mathrm{I}$ would assert that both present and hindsight accounts tell us something about the camps in which people live or lived. In both accounts, camp experiences resonate. From neither of them, in its singularity, can we infer a sole reality of the camp. If we thus treat the contradictory accounts and evaluations as being equally valid, instead of searching for the one correct assessment, we can gain insights from these discrepancies. Not only people move along flight and return routes, or other migration trajectories, but also their perceptions and horizons of orientation are in motion. Accordingly, not only can we ask how experiences are (re-)organized in biographic

\footnotetext{
15 From an oral history perspective, Allison (2016) offers such a diachronic comparison of Vietnam battle memories recorded in two different interviews. He focuses more on how a certain event is recounted than on evaluations, and he highlights the impact of different audiences, legitimatory needs, frames of reference, and the sense-making work of memory over time to account for the differences between descriptions immediately following the event versus those given decades later. I would not follow Allison (2016: 341) in his distinction between the "raw stark facts" associated with interviews done immediately after an event and "explanations, context, and interpretation" associated with interviews conducted years later. However, I do agree with his observation that opportunities to include accounts of experiences from different times in a diachronic comparison are (too) "few and far between" (Allison 2016: 341).

16 See Stoler 1992: 153, 183 f., who makes a similar argument in a synchronic comparison of different actors' voices speaking about a case of violence in a colonial context.
} 
narrations (see Rosenthal 1995: 167 ff.; Allison 2016: 339), but we can also trace changes in evaluations and emotional perceptions.

More concretely, from the discrepancies in pre- and post-return assessments of camps, we can learn about the different situations, flight and return phases, and horizons of orientation that are valid in the respective accounts. This allows us to position the refugee camp conceptually as one stage in the course of a flight trajectory, or of a mobility biography as its individually experienced form. ${ }^{17}$ Such an understanding of refugee camps as integrated in more encompassing flight (and possibly return) movements avoids the conceptual isolation of "the refugee camp" that frequently characterizes studies on refugee camps (including, to a large degree, my own; see Inhetveen 2010). Such isolating perspectives on camps entail advantages for research designs and problem formulations, and they echo the empirically prevalent spatial, administrative, and discursive isolation of refugee camps. They miss, however, the fact that for many refugees life in camps is one phase among others in their more encompassing mobilities (although other refugees spend their whole life in camps, a considerable number of which, like Meheba, exist for decades; see Loescher/Milner 2005).

It thus seems worthwhile to reposition refugee camps conceptually as stations in more encompassing flight trajectories (see also the remark by BenEzer/Zetter 2015: 312). Insights can be gained from changing meanings and evaluations of camp experiences, for example in respect of the changing relevance of different horizons of orientation. The materials from Zambian camps and from returnees in Angola point to different comparative references, which also depend on party affiliation. In addition, the comparative reference to which an evaluation points can be oriented towards the future or the past, or to suggested simultaneous life-worlds elsewhere (such as other refugee camps, where the inhabitants are frequently imagined as living in better conditions). This can be illustrated on the basis of our two research projects: In camp evaluations of livelihood conditions, Angola serves as a reference point both as a past and an expected future experience. For example, people compare the food rations with the plentiful and varied food they remember from earlier times in Angola and hope for in the future after repatriation; with regard to safety, they mainly remember their most recent experiences with war violence. In the interviews with returnees, the backdrop for better evaluations of camp life is often the perceived lack of recognition and care by the Angolan government and the difficult living conditions after return. Thus, the changing camp evaluations throw light on the disappointment of returnees regarding the situation in which they find themselves back in Angola. The Angola in relation to which the camp is evaluated has changed fundamentally in their experience during the course of their flight-andreturn trajectory.

17 With this understanding of 'mobility biographies', I depart from the term's understanding in transport and travel studies (for example Rau/Manton 2016), as I think in such a modified sense it points to useful angles and methodological approaches for (forced) migration research in the social sciences. 
UNITA affiliates among the refugees find themselves in a specific situation. Dominant views in Nangweshi saw the camp population as UNITA in exile, with hopes and spirit directed towards a future in an UNITA-governed Angola. Their comparative reference for the evaluation of camp life is mostly their life in Jamba, the UNITA stronghold in south-eastern Angola from which the refugee group in the main camp has fled. From a camp perspective, life in Jamba came off much better than life in Nangweshi Camp. Back in Angola, however, conditions in the camp are seen as positive mainly in relation to the post-return situation of UNITA affiliates. From this perspective, Nangweshi appears as being relatively close to Jamba (even though the latter cannot be equaled) insofar as both environments were characterized by non-discrimination (as UNITAs) and being-cared-for. The reevaluation of camp life seems connected to a disappearing confidence that the (life) world of UNITA, as the Nangweshi population had experienced it mainly in Jamba, could be realized in a post-return Angola any time soon. The situation of UNITA returnees thus resembles a "quasi-diaspora", spatially within Angola as the territory of felt (be-)longing, but temporally in unbridgeable distance from the world that they remember as realized in Jamba and had hoped for in a post-war Angola (Inglês et al. 2017: 113 ff.). ${ }^{18}$ While camp life in Zambia is remembered as being better than the current post-return situation in Angola, the longed-for world of UNITA is a horizon of comparison against which life in post-war Angola is even bleaker.

Changing camp accounts also give a differentiated picture of the perceived time dimension of refugee camps. Refugees' expectations and plans change over time. Also, they are often ambiguous and undecided at any given point - a camp situation might be tentatively perceived as permanent, or enduringly perceived as provisional, with varying degrees of confidence. Thus, the emphasis on specific options might vary even in a retrospective, post-return perspective. We cannot determine, at one point in time, whether a camp situation is permanent or transitional. Moreover, this property of camps - their "permanent temporariness" (Inhetveen 2010: 253; translation K.I.) ${ }^{19}$ or "indeterminate temporariness" (Turner 2016: 142) - in its relevance for the residents' actions and evaluations (see also Fellesson 2003) changes in the course of a flight trajectory.

Finally, the discrepancies between camp assessments in the course of flight trajectories show how careful we should be with seeing "the camp" as one empirically

\footnotetext{
18 Taking up the conceptualization by Oliver Bakewell (2008), one could speak of a not only intraAfrican, but intra-territorial diaspora, as the situation of UNITA returnees shares some of the core characteristics of diasporas that Bakewell discusses, namely (all verbatim quotes Bakewell 2008: 11) a "collective myth of an ideal ancestral home", a strong political (though not primarily ethnic as in Bakewell's criteria) "group consciousness sustained over a long time" (here based on both a shared history and a political vision), and a "sustained network of social relationships with members of the group living in different countries of settlement" - in this case in changing transnational constellations over time throughout the wars and the flight-and-return trajectory. As the criterion of dispersal or expansion across national borders is lacking, or rather replaced by a temporal distance, but the longing is more than the memory of a historical past, we speak of a "quasi-diaspora" and not a diaspora proper.

${ }^{19}$ I have conceptualized this in German as "dauerbafte Vorläufigkeit", which makes the camp inhabitants 'prevented wanderers' in the Simmelian sense (Inhetveen 2010: 253 ff.).
} 
determinable type of social order, and treating it conceptually as some prototypic state of affairs. When using "camp" as an analytic category, we should consider how versatile the camp is as an experienced and remembered reality.

Acknowledgments. My thanks go to the German Research Association (DFG) for funding both projects from which the material for this article has been drawn. The first project was "The political order of the refugee camp" (2003-2006), directed by Trutz von Trotha and located at the University of Siegen. The second was "Refugee return and local politics in Angola” (2011-2014), directed by myself (and, during my maternal leave, my LMU colleague Martin Sökefeld) and located at Ludwig-Maximilians-Universität München and the Universität der Bundeswehr München; the latter project was part of the DFG Priority Programme 1448 "Adaptation and Creativity in Africa". I also wish to take this opportunity to express my thanks to the respective project teams. Earlier versions of this paper were presented at the interdisciplinary conference "The Camp: Disruptions of Space and Time in Labour and Refugee Camps" at the University of Cologne in October 2018, and at the workshop "Konflikte, kommunikative Bewältigung und Grenzen der Aushandlung in Flüchtlingslagern und Unterkünften für Geflüchtete" at the German Anthropological Association Conference 2019 in Konstanz, and I would like to thank the participants for engaging in discussion of my ideas. Last but not least, my thanks go to the anonymous reviewer as well as the editors for their careful feedback and valuable suggestions.

\section{References}

Allison, F. (2016): Remembering a Vietnam War Firefight. Changing Perspectives Over Time. In: Perks, R./Thomson, A. (eds.): The Oral History Reader. 3rd ed. London/New York: Routledge, 334-342.

Amore, K. (2003): Repatriation or Deportation? When the Subjects have no Choice. In: Migration, 39/40/41, 153-171.

Bakewell, O. (2008): In Search of the Diasporas Within Africa. In: Diaspora, $1(1 / 2), 5-27$.

Barrett, M. (1998): Tuvosena: 'Let's Go Everybody'. Identity and Ambition Among Angolan Refugees in Zambia. Working Papers in Cultural Anthropology No. 8. Uppsala: Department of Cultural Anthropology, Uppsala University.

BenEzer, G./Zetter, R. (2015): Searching for Directions. Conceptual and Methodological Challenges in Researching Refugee Journeys. In: Journal of Refugee Studies, 28(3), 297-318.

Brinkman, I. (2007): Angolan Civilians in Wartime 1961-2002. In: Laband, J. (ed.): Daily Lives of Civilians in Wartime Africa. From Slavery Days to the Rwandan Genocide. Westport, CT/London: Greenwood Press, 169-194. 
Fellesson, M. (2003): Prolonged Exile in Relative Isolation. Long-term Consequences of Contrasting Refugee Policies in Tanzania. Uppsala: Acta Universitatis Upsaliensis.

Harrell-Bond, B. E. (1986): Imposing Aid. Emergency Assistance to Refugees. Oxford/New York/Nairobi: Oxford University Press.

Hoeing, W. (2004): Self-Image and the Well-Being of Refugees in Rhino Camp, Uganda. New Issues in Refugee Research, Working Paper No. 103. Geneva: UNHCR/EPAU.

Horst, C. (2006): Transnational Nomads. How Somalis Cope with Refugee Life in the Dadaab Camps of Kenya. New York/Oxford: Berghahn.

Inglês, P./Inhetveen, K./Kohl, C./Melo, A./Schmid, S. (2017): Zurückgekehrte Flüchtlinge und Lokalpolitik in Angola. Ein Forschungsbericht. In: Zeitschrift für Flüchtlingsforschung, 1(1), 106-123.

Inhetveen, K. (2006): “Because We Are Refugees". Utilizing a Legal Label. In: Zeitschrift für Rechtssoziologie, 27(1), 109-131.

Inhetveen, K. (2009): Bürgerkriegspartei im Flüchtlingslager. Importierte Machtstrukturen und das internationale Flüchtlingsregime. In: Maeder, C./Mäder, U./Schilliger, S. (eds.): Krieg - Guerre. Zürich: Seismo, 122-141.

Inhetveen, K. (2010): Die politische Ordnung des Flüchtlingslagers. Akteure Macht - Organisation. Eine Ethnographie im Südlichen Afrika. Bielefeld: transcript.

Inhetveen, K. (2012): Translation Challenges. Qualitative Interviewing in a MultiLingual Field. In: Qualitative Sociology Review, 8(2), 28-45. Online: www.qualitativesociologyreview.org/ENG/Volume22/QSR_8_2_Inhetveen.pdf $<15.03 .2020>$.

Loescher, G./Milner, J. (2005): Protracted Refugee Situations. Domestic and International Security Implications. London/New York: Routledge.

McConnachie, K. (2014): Governing Refugees. Justice, Order and Legal Pluralism. London/New York: Routledge.

Malkki, L. (1995): Purity and Exile. Violence, Memory, and National Cosmology Among Hutu Refugees in Tanzania. Chicago/London: University of Chicago Press.

Paret, M. (2018): Critical Nostalgias in Democratic South Africa. In: The Sociological Quarterly, 59(4), 678-696.

Pottier, J. (1996): Why Aid Agencies Need Better Understanding of the Communities They Assist. The Experience of Food Aid in Rwandan Refugee Camps. In: Disasters, 20(4), 324-337. 
Powles, J./Clark, J. (1996): Oral Testimony Project. Maheba Refugee Settlement Zambia 1996. A field report, for the conference on 'Reconstructing Livelihoods. Towards New Approaches to Resettlement'. Oxford, September 9-13, 1996.

Rau, H./Manton, R. (2016): Life Events and Mobility Milestones. Advances in Mobility Biography Theory and Research. In: Journal of Transport Geography, $52,51-60$.

Reed, A. R. (2016): Nostalgia in the Post-Apartheid State. In: Anthropology Southern Africa, 39(2), 97-109.

Rosenthal, G. (1995): Erlebte und erzählte Lebensgeschichte. Gestalt und Struktur biographischer Selbstbeschreibungen. Frankfurt a. M./New York: Campus.

Schubert, J. (2015): 2002, Year Zero. History as Anti-Politics in the 'New Angola'. In: Journal of Southern African Studies, 41(4), 1-18.

Silverman, D. (2010): Doing Qualitative Research. A Practical Handbook. 3rd ed. London: Sage.

Soares de Oliveira, R. (2015): Magnificent and Beggar Land. Angola since the Civil War. London: Hurst \& Company.

Sphere Project (2000): The Sphere Project. Humanitarian Charter and Minimum Standards in Disaster Response. Geneva.

Spradley, J. P. (1979): The Ethnographic Interview. New York: Holt, Rinehart and Winston.

Stoler, A. L. (1992): "In Cold Blood". Hierarchies of Credibility and the Politics of Colonial Narratives. In: Representations, 37, Winter 1992, Special Issue: Imperial Fantasies and Postcolonial Histories, 151-189.

Strauss, A. L. (1987): Qualitative Analysis for Social Scientists. Cambridge/New York/Melbourne: Cambridge University Press.

Turner, S. (2010): Politics of Innocence. Hutu Identity, Conflict and Camp Life. New York/Oxford: Berghahn.

Turner, S. (2016): What Is a Refugee Camp? Explorations of the Limits and Effects of the Camp. In: Journal of Refugee Studies, 29(2), 139-148.

Weigert, S. L. (2011): Angola. A Modern Military History, 1961-2002. New York: Palgrave Macmillan. 